\title{
BIODIVERSITY SURVEY OF GANDHISAGAR RESERVOIR, MADHYA PRADESH
}

\author{
Rakesh Vyas and Himmat Singh
}

Hadoti Naturalists Society, 2P22, Vigyan Nagar, Kota, Rajasthan 324005, India

\begin{abstract}
The paper presents the results of the biodiversity survey of Gandhisagar Dam situated on the state boundary of Madhya Pradesh and Rajasthan. Various methods were used to survey the macro diversity such as fishes, reptiles, birds, mammals and plants. Eight plant species were found among which Vallisneria spiralis was predominant. Faunal survey resulted in 21 species of fish, eight reptiles, 139 birds and one mammal species. Gandhisagar Reservoir is under threat due to human activities which has resulted in the gradual decrease of biodiversity in the region.
\end{abstract}

\section{KeYwords \\ Biodiversity, checklist, Gandhisagar Reservoir}

Gandhisagar Dam is a part of an ambitious project taken up to provide irrigation facilities and to generate hydel power, jointly, for the states of Madhya Pradesh and Rajasthan. The Chambal Valley Project was completed in three stages. In the first stage, Gandhisagar Dam and Kota Barrage were completed in 1960 and in later stages, Rana Pratap Sagar Dam and Jawaharsagar Dam were commissioned in 1970 and 1973, respectively. River Chambal originates at Janapao in Indore District and traverses a distance of $1,056 \mathrm{~km}$ before joining river Yamuna at Pachnada in Uttar Pradesh. The river meanders its way through Malwa and Hadoti plateau and passes through the great boundary fault between Vindhya and Aravalli Mountain ranges to finally emerge in the Gangetic Plains.

Gandhisagar Reservoir (GR) covers an area of $660 \mathrm{~km}^{2}$ making it one of the largest inland water bodies. Its catchment area is $23,025 \mathrm{~km}^{2}$ and it collects the major part of drainage discharge from Kshipra, Shivana, Retam, Chhoti Kali Sindh, Ansar, Rupania and Tilsoi rivers. The fresh water wetlands face multiple threats to their existence, which has caused a havoc on the fresh water resources of the country. Haphazard damming of rivers, deforestation in the catchment areas, civic and industrial waste disposal, release of untreated sewage, contamination with pesticide residue, eutrophication, soil erosion causing heavy siltation are some of the leading factors resulting in the death or annihilation of the fresh water resources.

The purpose of the study was to survey the macro diversity of the major inland wetlands of Madhya Pradesh and Chhattisgarh. The present paper is a result of the biodiversity survey of GR.

\section{STUdY AREA}

Gandhisagar Dam $\left(22^{\circ} 44^{\prime} \mathrm{N} \& 75^{\circ} 22^{\prime} \mathrm{E}\right)$ is situated on the state boundary of Madhya Pradesh and Rajasthan spreading over $660 \mathrm{~km}^{2}$. The reservoir at its full capacity is $399.9 \mathrm{~m}$ and its average area is $402 \mathrm{~km}^{2}$. The maximum length of the reservoir is $67.8 \mathrm{~km}$ and its maximum breadth is $26.1 \mathrm{~km}$. The construction of the dam was started in 1954 and it was commissioned in 1960. Two- hundred-and-twenty-eight villages were fully or partially submerged due to flooding. Full submergence is achieved, when the water level in the dam is spproximately $50 \mathrm{~m}$, but due to scanty rainfall in past three years, its capacity utilization has dropped by more than $40 \%$. During the study period in December-January 2001-2002, the water level was $381.9 \mathrm{~m}$, which resulted in reduction in the area of submergence by approximately $250 \mathrm{~km}^{2}$. Many large islands had reappeared in the reservoir and vast land on both the banks had been reallocated for cultivation by the state government. The technical details of the dam and the reservoir are provided in Table 5.

\section{Materials AND Methods}

The expanse of Gandhisagar Reservoir was covered by scanning both the banks from various points and extensive boat rides were undertaken to survey. On the eastern bank, the avian and floral diversity was observed from dam site, Modimata, Bhanpura, Kanwala, Raipuria and Pipalda, whereas on the west bank, observations were taken between Gandhisagar and Rampura by walking along the bank. Observations were made with a $8 \times 40$ Minolta and $10 \times 50$ Zenith binoculars and Konus telescope. The macro flora was collected from the banks as well as from shallower parts and islands during the boat and ferry rides. Fishes were taken at fish collection sites and fish dispatch depot of Madhya Pradesh Matsya Mahasangh Ltd. Fishes collected were sent for laboratory investigations at Salim Ali Centre for Ornithology and Natural History, Coimbatore. The mammalian, avian and reptilian diversity was personally observed and secondary information from reliable sources was collected.

\section{Results ANd Discussion}

The aquatic flora of Gandhisagar Reservoir shows predominance of riverine macrophytes. During the study period, eight plant species belonging to five genera were collected from the reservoir (Table 4). The GR is a vast expanse of deep and open water, having massive jungle of Vallisneria spiralis growing from a depth of approximately $4 \mathrm{~m}$. Rest of the plants were found in shallower marginal waters in thick clumps, intermingled with each other. The female flowers of Vallisneria, on their extremely long pedicels were most abundant in the month of January. Fortunately, GR and its feeder streams on the upstream side are free of Eichhornia, which is quite common after Jawaharsagar Dam and has become a menace to the canal system at Kota and downstream of Kota Barrage.

A detailed study on the fisheries in GR conducted by Rao et al. (1998) accounts for 41 species of fish. Another study conducted before the construction of the dam by Dubey et al. (1959), reported the occurrence of 54 species of fish from Chambal River in this region. Presently, it has become a Catla reservoir as it is the most abundant fish besides Rohu and Mrigal. Some of the 


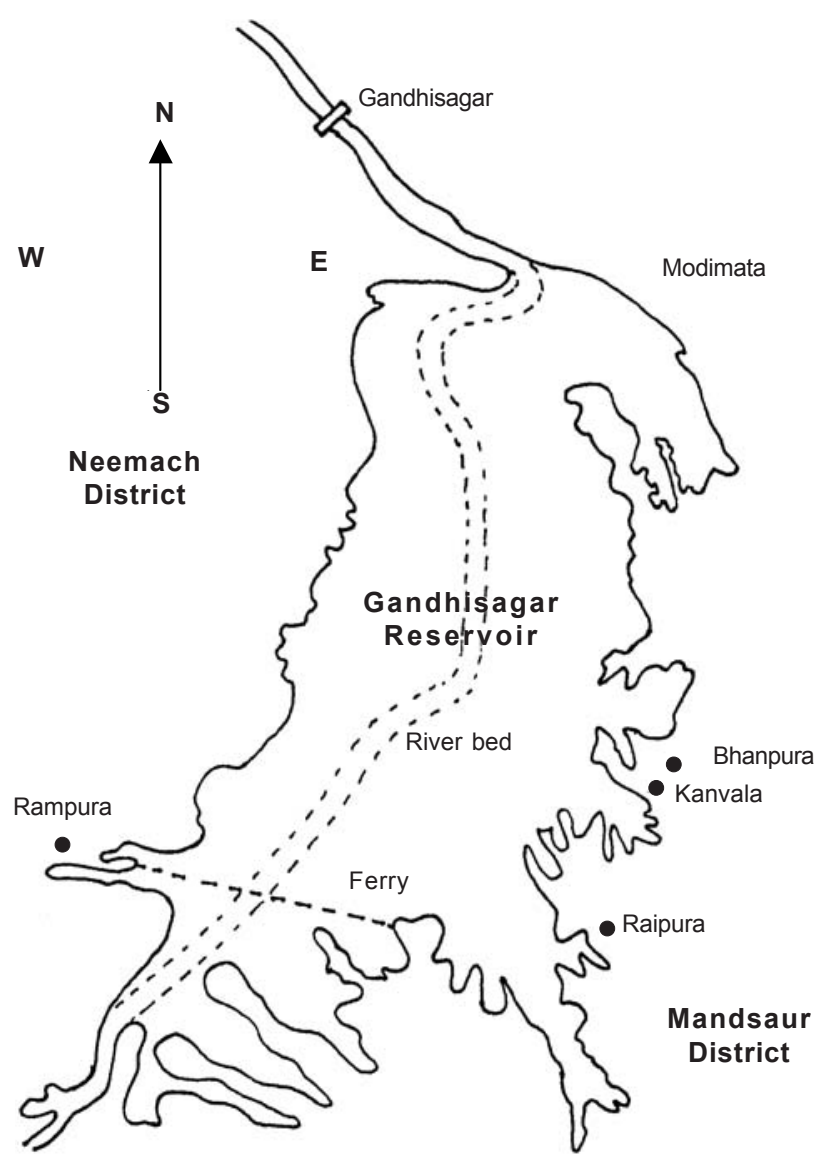

Figure 1. Gandhisagar Reservoir

other local major and local minor fishes are Labeo calbasu, $L$. gonius, L. bata, L. boggut, Ompok bimaculatus, Wallago attu and Cirrhinus reba. Among game fishes Mahseer is still found, though in smaller numbers and size (147 Mahseer caught in 2000-2001 together weighed just $386.5 \mathrm{~kg}$.). In the present survey, we could see and collect 21 species of fish, of which Chels laubaca has not been reported earlier by Rao et al. (1988). The fall in the fish diversity could be attributed to the change in wetland type from riverine to reservoir and also due to the promotion of commercial fisheries in which market-friendly species are introduced and stocked.

The family Crocodylidae was represented by one species Crocodylus palustris or Mugger. The species is fairly widely distributed throughout the length of the reservoir and looks to be fairly safe. The Gavial was neither seen by us nor reported by the fisherfolk, who are well acquainted with the area. Common Indian Monitor (Varanus bengalensis) was seen on the banks. Five species of turtles and one land tortoise were found (Table 2). Rao (1991) reported seven turtles from Chambal, out of which Kachuga dhongoka and Chitra indica were not found in GR but additionally, land tortoise Geochelone elegans was abundant on some of the islands. Reportedly, turtle egg and meat is consumed by Bengali fisherfolk working in the area. Kachuga kachuga, Aspideretus gangeticus and Lissemys punctata, protected under Schedule I of the Indian Wildlife (Protection) Act, 1972 occur in GR.

Smooth-coated Indian Otter Lutra perspicillata was a common sight throughout the length of the Chambal River. It has almost vanished downstream of Ranapratapsagar Dam and reappears only near Dholpur after a gap of almost $400 \mathrm{~km}$. The anecdotal accounts available at Kota suggest that until about 40 years back, it was a common sight in Chambal. We were particularly keen on reestablishing its prevent status. During this survey, we could record it from Gandhisagar and Ranapratapsagar reservoirs. Two otter families were sighted right below the guest house of the forest department at Gandhisagar. It was fairly common in all the suitable habitats, i.e., small fingers of shallow water in the rocky banks of the reservoir.

The avifauna of Chambal River and its environs was studied by Sharma et al. (1995), Vyas (1998), and, Rao (1988). These studies were primarily conducted in National Chambal Gharial Sanctuary between Kota and Morena. One-hundred-and-ninety-two bird species were reported by Vyas (1998), which included wetland and terrestrial birds. Since this survey was conducted during summer, a number of migratory waterfowls and waders could be included in this list from the earlier checklists prepared by Sharma (1995), and, Rao (1988). The present biodiversity study of GR is the first attempt to record avain diversity of this area. We recorded 139 species (Table 1) of birds from the environs of GR. It will be evident from the list that a number of marshland and sand bank inhabitants like waders, plovers, curlews, godwits, snipes have been recorded in large numbers, signifying the fact that by January each year vast land comes out of submergence and offers ideal feeding conditions to these birds. The presence of some of the exclusive piscivores like cormorants, darters, and terns were conspicuous due to their good numbers. Most of the geese and ducks common to central India were present, but prominent among them were Bar-headed Goose, Greylag Goose, Wigeon, Spotbilled Duck and Gadwal. The absence of Comb Duck and Cotton Teal is also noteworthy. The sighting of Sarus Crane and Common Crane is important in view of their present status. Sarus Crane is a threatened species in most of its earlier known home range.

We found that once the river enters the valley about $6 \mathrm{~km}$ upstream of the dam and $1 \mathrm{~km}$ on its downstream side, the numbers and sightings of vultures and other raptors increased significantly. Five species of vultures were sighted, including the Critically Endangered White-backed Vulture and Long-billed Vulture. Fortunately, both the vultures were breeding in the close vicinity of the reservoir. Imperial Eagle, Crested Serpenteagle, Osprey, Montagu's and Marsh Harrier, Kestrel and Whiteeyed Buzzard were some of the noteworthy raptors recorded from the study area. The immediate environs of the reservoir show a variety of ecosystems, which is reflected in their avian diversity. The forest on the west bank of GR is home to parakeets, owls, drongos, malkohas, treepie, Asian Paradise Flycatcher, White-browed Fantail-flycatcher and babblers. The drying margins of the reservoir support various wagtails and pipits. Larks, wheatear, chats, quails, partridge, sparrows and munias 
have been recorded from grassland habitat with scattered bushes.

It is evident that the GR supports a number of threatened mammal, bird, reptile and fish species and any alteration or degradation of this habitat due to natural or man-made causes may adversely affect its biodiversity. It is also obvious that man would not remain unaffected by these changes as his very survival depends upon the web of life supported by GR and its life sustaining water.

\section{$\underline{\text { Socio-economic impact of fisheries }}$}

Gandhisagar Reservoir, besides irrigating 1.70lakh hectare of farmland and producing $115 \mathrm{MW}$ of electricity, is a mega producer of freshwater fishes in the country. The fisheries operations have been channelised through a fisherman's co-operative federation, named Madhya Pradesh Matsya Mahasangh Ltd. This Mahasangh is a conglomerate of various smaller societies, which number 21 and have a membership of 1,896 individuals. In the year 2000-2001, 1,489 fishermen were directly or indirectly involved with fisheries operation and they comprised of various Bengali, Bhoi, Bihari, Kahar, Keer and Mallah communities.

The fish production has been falling over the last six years and has dropped from 2,965 metric ton in 1995-96 to $1,248.35$ metric ton in 2000-2001, thereby recording a fall of almost $60 \%$. The employment has remained almost constant as about 1,500 fishermen worked for 238, 149, 146, 177, 172 and 194, days between 1995-1996 and 2000-2001. The average market rate of the fish has also stagnated at about Rs. 11/- per kg. The average annual earning of a fisherman has come down to Rs. 20,485.00 in 2000-2001, which had peaked at Rs. 29,360.00 in the year 19981999. The annual report of the M.P.M.M.S. gives Rs.105.59 as the per day income of a fisherman, but if this income is annualized, then the per day income drops to Rs. 68.28 , which is well below the subsistence level.

A fisher's housing colony of 100 houses with water and electricity has been constructed at Rampura under National Fisherman Welfare Plan, but such initiatives are few and benefit fewer people. Health, sanitation, child education, women's welfare and training are some of aspects of life, which are in need of immediate attention of the management of M.P.M.M.S. Efforts should be made to provide alternative employment to fisherfolk during their lay-off periods, so as to augment their earning potential and keep them off antisocial activities.

\section{Threats and potential}

The wetland loss could be due to direct human action, indirect human activity or natural causes. Experts believed that Gandhisagar Dam would survive for 100 years but probably, the rate of environmental degradation and its possible impact was not taken into account. A dam management policy statement was also not made, which would have provided guidelines for various activities in the watershed areas of the reservoir. As a result, the reservoir has gotten filled, anywhere close to its capacity (over $396 \mathrm{~m}$ ), only during nine monsoon seasons in 23 years (1980-2002). The threats and existing potential of GR is enumerated below.

\section{Threats}

Direct and indirect human action:

a. Discharge of pesticides, herbicides - eutrophication, biotic loss; b. discharge of domestic sewage - eutrophication, change in $\mathrm{pH}$; c. agricultural run-off and sediment; d. alteration of upper watershed - construction of dams, anicuts on feeder streams; e. cultivation on thousands of hectares of dry reservoir bed in drought years; f. deforestation; g. introduced species - extinction of native biota.

The aesthetic, religious and historical importance of the river and reservoir for local people and its tourism potential have remained untapped.

Natural causes: a) drought, b) soil erosion

Potential: a) historical, archaeological and religious - tourism; b) biodiversity - forest resources, wildlife resources, fisheries, forage resources; c) recreation - boating, bird watching, nature walk, adventure sports.

\section{REFERENCES}

Ali, S. and D. Ripley (1983). Compact Handbook of the Birds of India and Pakistan. Oxford University Press

Cooke, T. (1967). The Flora of the Presidency of Bombay Part I, II, III. Botanical Survey of India

Daniel, J.C. (1992). The Book of Indian Reptiles. Oxford University Press

Dubey, G.P. and R.K. Mehra (1959). Fish and Fisheries of Chambal river, Proceedings of the All India Congress in Zoology 2: 647-665 (unpublished).

Hanfee, F. (1999). Field Guide to Freshwater Turtles and Tortoises of India. World Wide Fund for Nature, India

Lae, R. (1994). Effect of Drought, Dams and Fishing Pressure on the Fisheries of the Central Delta on the Niger River. International Journal of Ecology and Environmental Sciences 20: 119-120.

Madhya Pradesh Matsya Mahasangh (2001). Annual Report 20002001 (unpublished).

Manakadan R. and A. Pittie (2002). Standardised common and scientific names of the birds of the Indian Subcontinent. Newsletter for Birdwatchers Vol. 42: 3.

Prasad, V.P., D. Mason, J.E. Marburger and C.R. Ajithkumar (1996). Illustrated Flora of Keoladeo National Park Bharatpur, Rajasthan. Oxford University Press.

Prater, S.H. (1971). The Book of Indian Animals. Oxford University Press.

Rao K.S., K.N. Kartha, S. Shrivastava, S.S. Pandya and U. Choubey (1988). Studies of the Commercial Fisheries and its fluctuations in Gandhisagar Reservoir, Proceedings of the National Symposium Past, Present and Future of Bhopal Lakes: 55-65 (unpublished).

Rao, R.J. (1988). Nesting Ecology of the Gharial in National Chambal Sanctuary. Study report submitted to Wildfife Institute of India, 105pp. (unpublished).

Rao, R.J. (1991). Conservation of Freshwater Turtles in the National Chambal Sanctuary, study report submitted to Wildlife Institute of India, 105pp. (unpublished)

Sharma, R.K., R. Mathur and S. Sharma (1995). Status and Distribution of Fauna in National Chambal Sanctuary, Madhya Pradesli. Indian Forester 912-916.

Sonobe, K. (1993). A Field Guide to the Water Birds of Asia, Wildbird Society of Japan.

Vyas, R. (1998). Wildlife Survey Report on Fauna of National Chambal Gharial Sanctuary. 
Table 1. Systematic list of the birds of Gandhisagar Reservoir and its immediate environs

\begin{tabular}{|c|c|c|c|c|c|}
\hline Scientific name & Common name & Scientific name & Common name & Scientific name & Common name \\
\hline \multirow{5}{*}{$\begin{array}{l}\text { Podicipedidae } \\
\text { Phalacrocorax carbo } \\
\text { Phalacrocorax fuscicollis } \\
\text { Phalacrocorax niger } \\
\text { Tachybaptus ruficoffis }\end{array}$} & & & Waterhen & Mirafra erythroptera & Red-winged Bush Lark \\
\hline & Great Cormorant & Fulica atra & Common Coot & Galerida cristata & Common Crested Lark \\
\hline & $\begin{array}{l}\text { Indian Shag } \\
\text { Little Cormorant }\end{array}$ & $\underline{\text { Charadriidae }}$ & & $\underline{\text { Hirundinidae }}$ & \\
\hline & Little Grebe & Charadrius alesandrinus & Kentish Plover & Hirundo concolor & Dusky Crag-martin \\
\hline & & Charadrius dubius & Little Ringed Plover & Hirundo daurica & Red-rumped Swallow \\
\hline Anhingidae & & Vanellus indicus & Red-wettled Lapwing & Hirundo rustica & Common Swallow \\
\hline Anhinga melanogaster & Darter & Vanellus leucurus & White-tailed Lapwing & Hirundo smithii & Wire-tailed Swallow \\
\hline \multicolumn{2}{|l|}{ Ardeidae } & \multicolumn{2}{|l|}{ Scolopacidae } & \multicolumn{2}{|l|}{ Motacillidae } \\
\hline Ardea cinerea & Grey Heron & Actitis hypoleucos & Common Sandpiper & $\overline{\text { Anthus rufulus }}$ & Paddyfield Pipit \\
\hline Ardeola grayii & Indian pond-heron & Calidris minuta & Little Stint & Anthus spinoletta & Water Pipit \\
\hline Bubulcus ibis & Cattle Egret & Calidris temminckii & Temminck's Stint & Motacilla alba & White Wagtail \\
\hline Butorides striatus & Little Green Heron & Gallinago gallinago & Common Snipe & Motacilla cinerea & Grey Wagtail \\
\hline Casmerodius albus & Large Egret & Limosa limosa & Black-tailed Godwit & Motacilla maderaspatensis & Large Pied Wagtail \\
\hline Egretta garzetta & Little Egret & Numenius arquata & Eurasian Curlew & & \\
\hline Mesophoyx intermedia & Mediian Egret & Philomachus pugnax & Ruff & $\frac{\text { Pycnonotidae }}{\text { Pycnonotus cafer }}$ & Red-vented Bulbul \\
\hline \multicolumn{2}{|l|}{ Ciconiidae } & Tringa erythropus & Spotted Redshank & Pycnonotus cafer & \\
\hline Ciconia episcopus & White-necked Stork & Tringa glareola & Wood Sandpiper & Turdinae & \\
\hline Ciconia nigra & Black Stork & Tringa nebularia & Common Greenshank & Cercomela fusca & Indian Chat \\
\hline Myeteria leueocephala & Painted Stork & Tringa ochropus & Green Sandpiper & Chrysomma sinense & Yellow-eyed Babbler \\
\hline \multirow{2}{*}{\multicolumn{2}{|c|}{ Threskiornithidae }} & Tringa stagnatilis & Marsh Sandpiper & Oenanthe picata & Variable Wheatear \\
\hline & & Tringa totanus & Common Redshank & Oenanthe isabellina & Isabelline Wheatear \\
\hline Platalea leucorodia & Eurasian Spoonbill & & & Phoenicurus ochruros & Black Redstart \\
\hline Pseudibis papillosa & Black Ibis & $\frac{\text { Recurvirostridae }}{\text { Himantopus himantopus }}$ & Black-winged Stilt & Saxicola caprata & Pied Bushchat \\
\hline \multicolumn{2}{|l|}{$\underline{\text { Anatidae }}$} & & & Saxicola torquata & Common Stonechat \\
\hline Anas acuta & Northern Pintail & Burhinıdae & & Saxicoloides fulicata & Indian Robin \\
\hline Anas clypeata & Northern Shoveller & Esacus recurvirostris & Great Stone-Plover & Turdoides malcolmi & Large Grey Babbler \\
\hline Anas crecca & Common Teal & $\underline{\text { Laridae }}$ & & & \\
\hline Anas penelope & Eurasian Wigeon & Chlidonias hybridus & Whiskered Tern & Sylviinae & \\
\hline Anas poecilorhyncha & Spot-billed Duck & Larus brunnicephalus & Brown-headed Gull & Culicicapa ceylonensis & Grey-headed \\
\hline Anas querquedula & Garganey & Larus ichthyaetus & Pallas's Gull & & Flycatcher \\
\hline Anas strepera & Gadwall & Larus ridibundus & Black-headed Gull & Ficedula parva & Red-throated \\
\hline Anser anser & Greylag Goose & Sterna acuticauda & Black-bellied Tern & & Flycatcher \\
\hline Anser indicus & Bar-headed Goose & Sterna aurantia & River Tern & Phylloscopus collybita & Common Chiffchaff \\
\hline Aythya ferina & Common Pochard & \multicolumn{2}{|l|}{ Columbidae } & Sylvia curruca & Common Lesser \\
\hline \multirow{2}{*}{$\begin{array}{l}\text { Aythya fuligula } \\
\text { Tadorna ferruginea }\end{array}$} & Tufted Pochard & Columba livia & Blue Rock Pigeon & & Whitethroat \\
\hline & Brahniiny Shelduck & $\begin{array}{l}\text { Columba IIVIa } \\
\text { Streptopelia chinensis }\end{array}$ & $\begin{array}{l}\text { Blue Rock PIgeon } \\
\text { Spotted Dove }\end{array}$ & Monarchinae & \\
\hline \multicolumn{2}{|l|}{ Accipitridae } & Streptopelia decaocto & Eurasian Collared- & Terpsiphone paradisi & Asian Paradise- \\
\hline Accipiter badius & Shikra & & Dove & & Flycatcher \\
\hline Aquila heliaca & Eastern Imperial Eagle & Streptopelia senegalensis & Little Brown Dove & & \\
\hline Butastur teesa & White-eyed Buzzard & Treron phoenicoptera & Yellow-legged Green- & $\frac{\text { Rhipidurinae }}{\text { Rhinidura }}$ & \\
\hline Circus acruginosus & Western Marsh-Harrier & & Pigeon & Rhipidura aureola & White-browed Faintail- \\
\hline \multirow{3}{*}{$\begin{array}{l}\text { Circus pygargus } \\
\text { Elanus eacrulcus } \\
\text { Gyps bengalensis }\end{array}$} & Montagu's Harrier & \multicolumn{2}{|l|}{ Psittacidae } & & \\
\hline & Black-shouldered Kite & Psittacula cyanocephala & & $\underline{\text { Nectariniidae }}$ & \\
\hline & $\begin{array}{l}\text { Indian White-backed } \\
\text { Vulture }\end{array}$ & Psittacula krameri & Rose-ringed Parakeet & $\overline{\text { Nectarinia asiatica }}$ & Purple Sunbird \\
\hline Gyps indicus & Long-billed Vulture & Cuculidae & & Estrildidae & \\
\hline Gyps fulvus & Eurasian Griffon & Centropus sinensis & Greater Coucal & 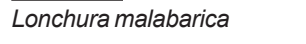 & White-throated Munia \\
\hline Gyps tenuirostris & Slender-billed Vulture & Eudynamys scolopacea & Asian Koel & Passerinae & \\
\hline Milvus migrans & Black Kite & & & $\overline{P a s s e r \text { domesticus }}$ & House Sparrow \\
\hline Neophron percnopterus & Egyptian Vulture & Strigidae & & Petronia xanthocollis & Yellow-throated \\
\hline Sarcogyps calvus & Red-headed Vulture & Athene brama & Spotted Owlet & & Sparrow \\
\hline & Crested Serpent-Eagle & Caprimulgidae & & Sturnidae & \\
\hline Pandionidae & & Apus affinis & House Swift & Acridotheres ginginianus & Bank Myna \\
\hline Pandion haliaetus & Osprey & Caprimulgus asıatıcus & $\begin{array}{l}\text { Common Indian } \\
\text { Nightjar }\end{array}$ & Acridotheres tristis & Common Myna \\
\hline Falconidae & & & & Sturnus contra & Asian Pied Starling \\
\hline Falco tinnunculus & Common Kestrel & $\frac{\text { Alcedinidae }}{\text { Alcedo attihis }}$ & & Oriolidae & \\
\hline Phasianidae & & Ceryle rudis & Lesser Pied Kingfisher & Oriolus oriolus & Eurasian Golden Oriole \\
\hline Francolinus pondicerianus & Grey Francolin & Halcyon smyrnensis & White-breasted & Dicruridae & \\
\hline Pavo cristatus & Indian Peafowl & & Kingfisher & Dicrurus caerulescens & White-bellied Drongo \\
\hline Turnicidae & & Meropidae & & Dicrurus macrocercus & Black Drongo \\
\hline Turnix suscitator & Common Buttonquail & Merops orientalis & Small Bee-eater & Corvidae & \\
\hline Turnix tanki Blyth & Yellow-legged & Merops philippinus & Blue-tailed Bee-cater & Corvus macrorhynchos & Jungle Crow \\
\hline & Buttonquail & Coraciidae & & Corvus splendens & House Crow \\
\hline Gruidae & & Coracias benghalensis & Indian Roller & Dendrocitta vagabunda & Indian Treepie \\
\hline Grus antigone & Sarus Crane & & & & \\
\hline Grus grus & Common Crane & $\frac{\text { Alaudidae }}{\text { Eremopterix grisea }}$ & Ashy-crowned & $\begin{array}{l}\text { Common and scientific nam } \\
\text { Pittie (2002). }\end{array}$ & s alter iviarlakauam al \\
\hline Rallidae & & & Sparrow-Lark & & \\
\hline$\overline{\text { Amaurornis phoenicurus }}$ & White-breasted & Mirafra cantillans & Singing Bush-Lark & & \\
\hline
\end{tabular}


Table 2. Reptiles and mammals of Gandhisagar Reservoir

\begin{tabular}{|c|c|}
\hline Scientific name & English name \\
\hline \multicolumn{2}{|l|}{ Reptiles } \\
\hline Crocodylus palustris & Mugger \\
\hline Geochelone elegans & Indian Star Tortoise \\
\hline Kachuga tentoria & Indian Tent Turtle \\
\hline Kachuga kachuga & $\begin{array}{l}\text { Red-crowned Roofed } \\
\text { Turtle }\end{array}$ \\
\hline Aspideretus gangeticus & Indian Softshell Turtle \\
\hline Lissemys punctata & Indian Flapshell Turtle \\
\hline Hardella thurjii & Crowned River Turtle \\
\hline Varanus bengalensis & Goh \\
\hline \multicolumn{2}{|l|}{ Mammal } \\
\hline Lutra perspicillata & Smooth Indian Otter \\
\hline
\end{tabular}

\section{ACKNOWLedgement}

The funding for the survey was provided to the first author by Salim Ali Centre for Ornithology and Natural History, Coimbatore, under UNDP - Govt. of India project, which is thankfully acknowledged. We are personally thankful to Dr. Lalita Vijayan and Dr. R.J. Rao, who provided us an opportunity and guidance to undertake this very important and interesting project. The support of the Department of Forests, Govt. of Madhya Pradesh and managing staff of Gandhisagar Wildlife Sanctuary, particularly Mr. Nizam Quereshi, ACF and incharge GSWLS, Mr. R.S. Yadav, RFO, Mr. Joshi and Mr. Bal Mukand is thankfully acknowledged. Mr. P.L. Gaur provided useful information on fishes of the area and helped with the collection of samples for laboratory examination at SACON. We are grateful to all the fisherfolk, villagers and other members of Madhya Pradesh Matsya Mahasangh, who shared some very useful information on biodiversity of the area. $\mathrm{Mr}$. A.H. Zaidi accompanied the authors on the survey and provided photographic support to the study. We are thankful to Mr. Rahul Choudhary and Mr. R.S. Tomar for their support during the study.
Table 3. List of freshwater fishes of Gandhisagar Reservoir (Rao et al., 1998)

\begin{tabular}{lll}
\hline Scientific name & & Scientific name \\
\cline { 1 - 1 } Cyprinidae & & Ceratophyllum demersum \\
\cline { 1 - 2 } Subfamily: Cyprininae & & Chara sp. \\
${ }^{*}$ Catla catla & Hydrilla verteoelata \\
${ }^{* *}$ Chela laubaca & Najas graminea \\
${ }^{*}$ Cirrhinus mrigala & Najas minor \\
${ }^{*}$ Cirrhinus reba & Potamogeton crispus \\
Crossochelius botia & Potamogeton pectinatus \\
Garra gotyla & Vallisneria spiralis
\end{tabular}

Labeo bata

Labeo boggut

* Labeo calbasu

* Labeo gonius

* Labeo rohita

Osteobrama cotio

Oxygaster bacaila

Oxygaster clupeoides

${ }^{*}$ Puntius surana

Puntius ticto

Subfamily Rasborinae

Barilius barila

Barilius bengalensis

Barilius bota

Danio devamo

* Rasbora daniconius

Subfamily Schizothoracinae

${ }^{*}$ Tor tor

Subfamily Gobitidnae

Nemachelius botia

Centropomicae

Ambassis nama

Ambassis ranga

Channidae

Channa marulius

Channa punctatus

*Channa striatus

Mugilidae

${ }^{*}$ Rhinomugil carsula

Mastacembelidae

*Mastacembalus armatus

Nanidae

Nandus nandus

Gobinae

*Glossogobius giuris

Belonidae

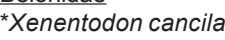

Siluridae

*Ompok bimaculatus

*Wallago attu

Bagridae

Mystus aor

*Mystus seenghala

Rita rita

Sisoridae

Bagarius bagarius

Schielbeidae

*Eutropiethys bacha

* Silonia silondia

Notopteridae

Notopterus notopterus

*Seen during the recent survey; ${ }^{* *}$ not reported earlier
Table 4. List of Aquatic vegetation of Gandhisagar Reservoir

Scientific name

Ceratophyllum demersum

Vallisneria spiralis

Table 5. Statistical details of Gandhisagar Dam and Reservoir

\begin{tabular}{ll}
\hline Geographical location & $24^{0} 44^{\prime} \mathrm{N} ; 7^{0} 33^{\prime} \mathrm{E}$ \\
Construction commenced & 1954 \\
Completed & 1960 \\
Catchment & $23,025 \mathrm{~km}^{2}$ \\
Av. rainfall & $86.4 \mathrm{CM}$ \\
Minimum & $35.6 \mathrm{CM}$ \\
Length of the dam & $514 \mathrm{~m}$ \\
Max. height & $62.2 \mathrm{~m}$ \\
Reservoir area at full capacity & $660 \mathrm{~km}^{2}$ \\
Av. Area of the reservoir & $402 \mathrm{~km}^{2}$ \\
Av. River bed & $341.4 \mathrm{~m}$ \\
Max. water level & $399.8 \mathrm{~m}$ \\
Max. length of reservoir & $67.8 \mathrm{~km}$ \\
Max. breadth of reservoir & $26.1 \mathrm{~km}$ \\
Max. Depth & $33.4 \mathrm{~m}$ \\
Av. Depth & $58.4 \mathrm{~m}$ \\
Total capacity of reservoir & $8,440 \mathrm{Mio} . \mathrm{m}^{3}$ \\
Electricity generation & $30,000 \mathrm{kw}$ \\
Expected age & $100 \mathrm{yr}$ \\
Funds invested - Dam & $\mathrm{Rs} .16 .6 \mathrm{Cr}$ \\
Electricity generation centre & $\mathrm{Rs} .4 .79 \mathrm{Cr}$ \\
\hline
\end{tabular}
Electricity generation centre Rs.4.79Cr 